\title{
Non-penetrance in a MODY 3 family with a mutation in the hepatic nuclear factor $1 \alpha$ gene: implications for predictive testing
}

\author{
Z Miedzybrodzka ${ }^{1}$, AT Hattersley ${ }^{2}$, S Ellard ${ }^{2}$, D Pearson ${ }^{4}$, D de Silva ${ }^{1}$, R Harvey $^{3}$ and \\ $\mathrm{N}$ Haites $^{1}$ \\ ${ }^{1}$ Medical Genetics, University of Aberdeen Medical School, Aberdeen \\ ${ }^{2}$ Department of Vascular Medicine and Diabetes Research, Postgraduate Medical School, Exeter, England \\ ${ }^{3} \mathrm{Dr}$ Gray's Hospital, Elgin \\ ${ }^{4}$ Diabetic Clinic, Aberdeen Royal Hospital NHS Trust, Aberdeen, Scotland, UK
}

\begin{abstract}
The most common cause of maturity-onset diabetes of the young (MODY) is a mutation in the hepatic nuclear factor $1 \alpha(H N F 1 \alpha)$ gene (MODY3). We describe a family in which a missense mutation causing a Thr-Ile substitution at codon 620 has been found in all affected members. The mutation is not fully penetrant as two family members aged 87 and 46 have the mutation but do not have diabetes. The severity and age of diagnosis of diabetes varies widely within the family, and most presented over the age of 25 . HNF1a mutation screening should be considered in any family with autosomal dominant inheritance of diabetes where one member has presented with diabetes before the age of 25 . Predictive testing is now possible within the majority of MODY families, and is of clinical benefit, but the possibility of non-penetrance should be addressed during counselling and interpretation of results.
\end{abstract}

Keywords: diabetes; HNF1 ; maturity onset diabetes of the young; MODY; MODY3; predictive testing

\section{Introduction}

Maturity-onset diabetes of the young (MODY) is an autosomal dominant form of non-insulin dependent diabetes mellitus (NIDDM) with early age of onset, often before the age of $25 .{ }^{1}$ MODY is caused by mutations in at least five different genes, namely hepatic nuclear factor $4 \alpha$ (MODY1), glucokinase

Correspondence: Dr Zosia Miedzybrodzka, Medical Genetics, Medical School, Foresterhill, Aberdeen AB25 2ZD, Scotland, UK. Tel: 01224 840749; Fax: 01224 662839; E-mail: zosia@abdn.ac.uk

Received 9 September 1998; revised 7 April 1999; accepted 15 April 1999
(MODY2), hepatic nuclear factor $1 \alpha$ (HNF1 $\alpha$; MODY3), insulin promotor factor1 (IPF1; MODY4) and $H N F 1 \beta$ (MODY5). ${ }^{2}$ Mutations in the HNFl $\alpha$ gene are the commonest cause of MODY, and found in up to $73 \%$ of UK MODY families. ${ }^{3} H N F 1 \alpha$ is a transcription factor involved in the regulation of gene expression in a number of tissues including the liver and pancreatic beta cells. We describe a family with autosomal dominant inheritance of diabetes in which a mutation has been found within the $H N F 1 \alpha$ gene, to alert others to the identification of MODY3 families, and to draw attention to the variable expression of the disorder, with particular reference to genetic counselling and predictive testing. 


\section{Case Report}

We report a family with a missense mutation in exon 10 of the HNF1 $\alpha$ gene, resulting from a Thr-Ile substitution at codon 620 (T620I). ${ }^{3}$ The pedigree is shown in Figure 1 and the clinical details are shown in Table 1. All the affected individuals were heterozygous for the T620I mutation. Age of diagnosis ranged from 16 to 67 (mean $=40)$.

$\mathrm{III}_{5}$ carries the mutation but does not have diabetes. At the age of 87 , she has a normal oral glucose tolerance test (venous plasma glucose $4.2 \mathrm{mmol} / \mathrm{l}$ fasting, $6.9 \mathrm{mmol} / \mathrm{l}$ at $120 \mathrm{~min}$ ). Haemoglobin $\mathrm{A} 1 \mathrm{c}$ was $5.6 \%$. Her present height is $1.4 \mathrm{~m}$, weight is $38 \mathrm{~kg}$ and BMI is $19.4 \mathrm{~kg} / \mathrm{m}^{2}$. Previous to the development of an osteoarthritic kyphosis, her height was $1.57 \mathrm{~m}$ and her weight was $57 \mathrm{~kg}$, giving a BMI of $23.1 \mathrm{~kg} / \mathrm{m}^{2}$. The diagnosis of diabetes was made in her son $\left(\mathrm{IV}_{2}\right)$ at the age of 58 , he did not carry the mutation but was obese (BMI $32.3 \mathrm{~kg} / \mathrm{m}^{2}$ ).

$\mathrm{IV}_{11}$ was noted to have glycosuria at age 19 , but his fasting blood glucose was then normal. Following identification of the mutation at the age of 46 , he continues to have a trace of glycosuria on dipstick urine analysis, but a fasting venous plasma glucose was $5.0 \mathrm{mmol} / \mathrm{l}$ and his haemoglobin A1c was $4.3 \%$ (normal range $<5 \%$ ), suggesting that he remains unaffected. An OGTT has not been possible. He is thin (BMI $\left.21.3 \mathrm{~kg} / \mathrm{m}^{2}\right)$.

\section{Discussion}

This family demonstrates considerable variation in the phenotype associated with a single missense mutation in HNF1a. One woman with the mutation is not diabetic at 87 , and those with diabetes vary considerably in the age of diagnosis, treatment requirements and diabetes associated complications.

The mutation in this family (T620I) is located at the $3^{\prime}$ end of the HNF1 a gene which encodes a 631 amino acid protein. T620I is likely to be pathogenic rather than a rare polymorphism because

(1) the amino acid threonine is conserved at codon 620 in the rat, human, hamster and chicken HNF1 $\alpha$ proteins;

II
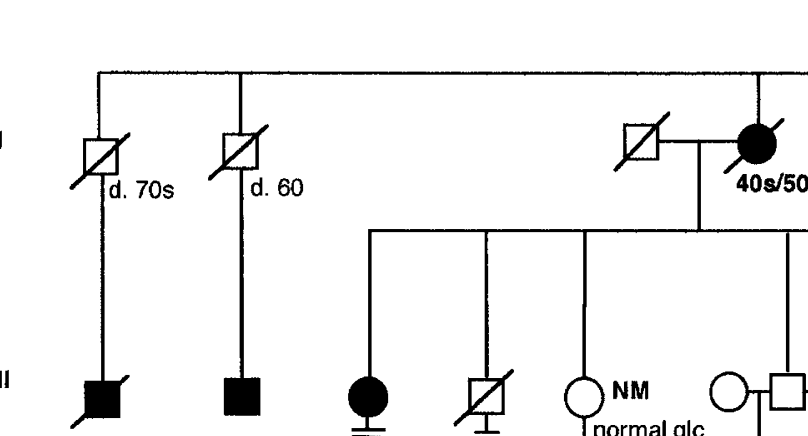

III
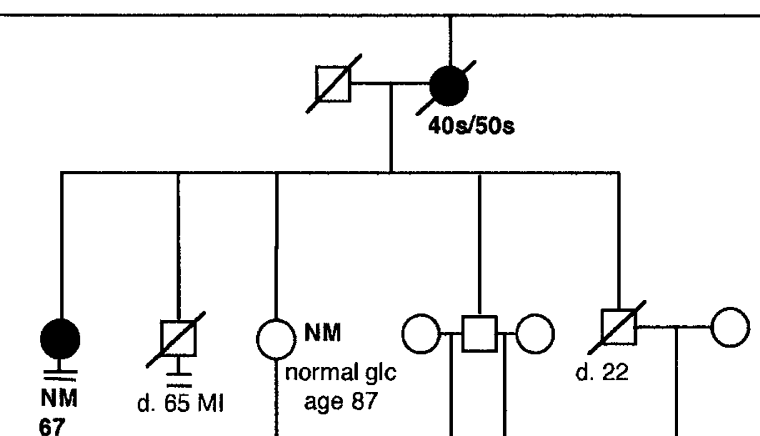

IV

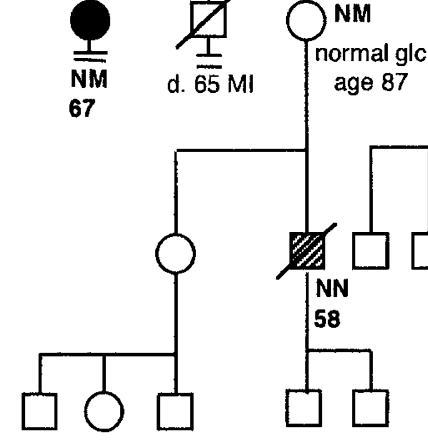

v

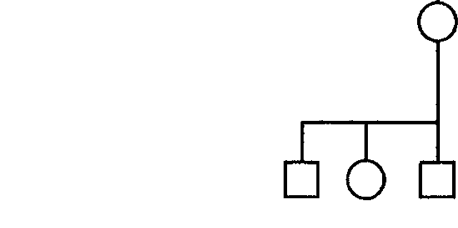

vi
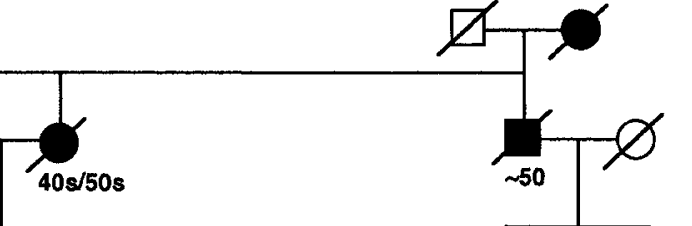

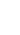
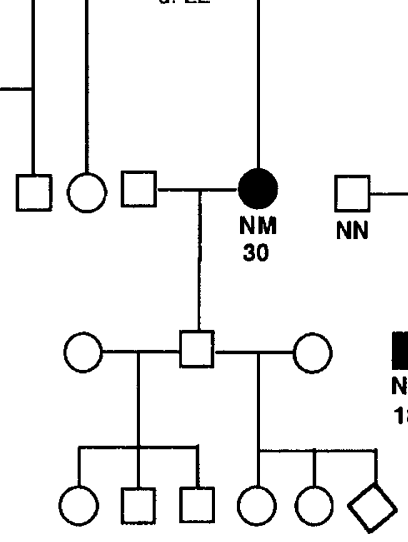
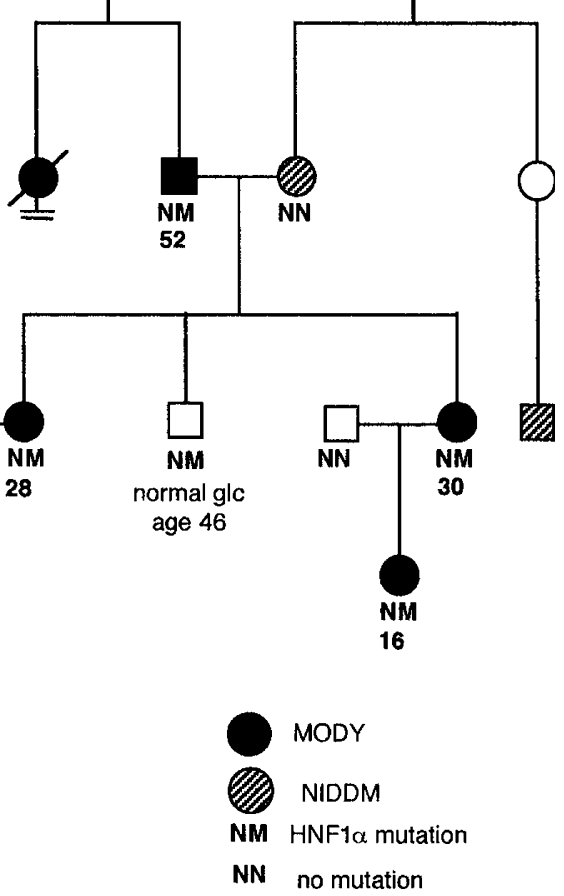

NN no mutation

bold figures age of onset

Figure 1 Pedigree indicating affected individuals and age of diagnosis of diabetes 
Table 1 Diabetic phenotype of affected individuals

\begin{tabular}{|c|c|c|c|c|c|c|c|}
\hline Individual & $\begin{array}{l}\text { HNFI } \\
\text { Mutation } \\
\text { present? }\end{array}$ & $\begin{array}{l}\text { Age of } \\
\text { diagnosis }\end{array}$ & $\begin{array}{l}B M 1 \\
\left(\mathrm{~kg} / \mathrm{m}^{2}\right)\end{array}$ & $\begin{array}{l}\text { Present age/ } \\
\text { Age at } \\
\text { death }(\text { d. })\end{array}$ & Presenting symptoms & Treatment & Complications \\
\hline $\mathrm{I}_{2}$ & $?$ & $?$ & & d. 75 & $\mathrm{n} / \mathrm{a}$ & diet & $\mathrm{n} / \mathrm{a}$ \\
\hline \multirow[t]{2}{*}{$\mathrm{II}_{4}$} & $?$ & $40 \mathrm{~s}$ & & d. 70 & 'blindness' & $\begin{array}{l}\text { insulin (nil else } \\
\text { possible) }\end{array}$ & 'blindness' \\
\hline & & & & & & & d. 'stroke' \\
\hline \multirow[t]{3}{*}{$\mathrm{II}_{5}$} & $?$ & $50 \mathrm{~s}$ & & d. 56 & 'nearly blind' & insulin & 'blindness' \\
\hline & $?$ & $?$ & & $?$ & $\mathrm{n} / \mathrm{a}$ & $\mathrm{n} / \mathrm{a}$ & $\mathrm{n} / \mathrm{a}$ \\
\hline & $?$ & $?$ & & $?$ & $\mathrm{n} / \mathrm{a}$ & $\mathrm{n} / \mathrm{a}$ & $\mathrm{n} / \mathrm{a}$ \\
\hline $\mathrm{III}_{3}$ & + & 67 & 23.9 & 85 & thirst, polyuria & tolbutamide & $\begin{array}{l}64 \text { ischaemic heart } \\
\text { disease } \\
75 \text { femoral embolectomy }\end{array}$ \\
\hline $\mathrm{III}_{11}$ & $?$ & late $50 \mathrm{~s}$ & & d. ? age & $\mathrm{n} / \mathrm{a}$ & $\mathrm{n} / \mathrm{a}$ & $\mathrm{n} / \mathrm{a}$ \\
\hline $\mathrm{III}_{12}$ & + & 52 & 26.3 & 80 & $\begin{array}{l}\text { pregangrenous toe, } \\
\text { fatigue, polydypsia }\end{array}$ & $\begin{array}{l}\text { Chlorpropamide, } \\
\text { tolbutamide, glipizide }\end{array}$ & $\begin{array}{l}62 \text { diabetic neuropathy } \\
73 \text { diabetic retinopathy } \\
80 \text { intermittent } \\
\text { claudication }\end{array}$ \\
\hline $\mathrm{IV}_{8}$ & + & 30 & 26.3 & 55 & pruritis vulvae & metformin & - \\
\hline $\mathrm{IV}_{10}$ & + & 28 & 25.5 & 54 & $\begin{array}{l}\text { pruritis vulvae, poly- } \\
\text { dypsia, frequency. } \\
\text { Glycosuria but not } \\
\text { diabetic during pregnancy }\end{array}$ & tolbutamide & - \\
\hline $\mathrm{IV}_{13}$ & + & 30 & 22.1 & 41 & $\begin{array}{l}\text { thirst, polyuria, weight } \\
\text { loss, vulvovaginitis }\end{array}$ & glipizide & recurrent vulvovaginitis \\
\hline $\mathrm{V}_{9}$ & + & 18 & 24.9 & 30 & chance blood test & insulin & - \\
\hline $\mathrm{V}_{10}$ & + & 16 & 23.0 & 21 & $\begin{array}{l}\text { dry mouth, pruritis } \\
\text { vulvae }\end{array}$ & diet & - \\
\hline
\end{tabular}

n/a: not available

(2) the substitution of isoleucine results in the replacement of an uncharged polar amino acid by a nonpolar amino acid; and

(3) this mutation was not found in 200 normal chromosomes.

Unequivocal classification of this sequence variant as a pathogenic mutation requires functional studies.

The non-penetrant 87-year-old female $\left(\mathrm{III}_{5}\right)$ is the oldest reported unaffected subject with an $H N F 1 \alpha$ mutation. Of the 37 British families with $H N F 1 \alpha$ mutations studied to date, non-penetrance is rare over $25,^{3}$ and this is the only family in which the mutation has been found in unaffected individuals over the age of 40 (Ellard, Frayling, Bulman and Hattersley 1998, personal communication).

Both $\mathrm{III}_{5}$ and $\mathrm{IV}_{11}$ have been thin throughout their lives, and a low BMI may have helped to prevent the onset of diabetes by increasing insulin sensitivity, and thus the ability to cope with the defective insulin secretion seen in MODY3. ${ }^{4}$ Lehto et al showed that subjects with $H N F 1 \alpha$ mutations that were not diabetic were thinner than diabetic subjects. ${ }^{5}$ In keeping with this, the mutation carriers in this family with diabetes have generally higher BMIs than those without diabetes, although there is an overlap. We suggest that it would be reasonable to offer advice on diet and exercise to those at risk in a MODY family. 
The history of older family members presenting with visual loss from diabetic retinopathy is a reminder that MODY3 patients are at risk of complications, and hence early diagnosis and appropriate treatment of hyperglycaemia are important. ${ }^{6}$ The appropriate treatment may be diet, oral hypoglycaemic agents or insulin. Physiological studies have suggested that there is a progressive deterioration in beta-cell function with age; thus many subjects will have increasing treatment requirements as they get older. This is in marked contrast to patients with mutations in the glucokinase gene (MODY2), who show relatively little deterioration in beta-cell function with time. The majority of these subjects only need dietary advice and are not at risk of microvascular complications. ${ }^{7}$ Predictive testing of MODY3 using mutation analysis would enable early diagnosis and treatment of diabetes, avoid follow up for unaffected individuals, and pre-symptomatic life-style advice, such as diet, might alter the course of the disease.

In this family genetic testing demonstrated that individual $\mathrm{IV}_{2}$ has non-insulin dependent diabetes mellitus (NIDDM) rather than MODY, illustrating the use of mutation analysis to confirm diagnosis and to differentiate MODY from familial clustering of the polygenic NIDDM and IDDM. This emphasises that a negative predictive test would not exclude the possibility of developing IDDM or NIDDM.

In summary, our pedigree shows that the age of diagnosis and severity of diabetes in MODY may be very variable. The diagnosis may be made in several family members after the age of 25 , and some may require insulin, even if they are not insulin dependent. In a family with autosomal dominant inheritance of diabetes, the diagnosis of MODY should be considered if one affected individual presents under the age of 25 . Mutation analysis may be used to confirm diagnosis and predictive testing may then be possible. However, caution should be exercised in predictive testing, as those who do not inherit the mutation may develop other forms of diabetes, and those with the mutation may never develop the disease, or may develop it late.

\section{Acknowledgements}

We wish to thank the family and especially Drs McDowall, Shaw, Heneghan, Cunningham, Peters and Kennedy and Genetic Nurse Kate Sarson, who went well out of their way to help to trace family members and to collect blood samples. Genetic analysis was funded by the British Diabetic Association, the Medical Research Council and the Northcott Devon Medical Foundation.

\section{References}

1 Hattersley AT: Maturity-onset diabetes of the young: clinical heterogeneity explained by genetic heterogeneity. Diabetic Med 1998; 15: 15-24.

2 Horikawa $\mathrm{Y}$, Iwasaki N, Hara $\mathrm{M}$ et al: Mutation I hepatocyte nuclear factor-1 beta gene (TCF2) associated with MODY. Nat Genet 1997; 17: 384-385.

3 Frayling T, Bulman MP, Ellard S et al: Mutations in the Hepatocyte Nuclear Factor 1 Alpha gene are a common cause of maturity-onset diabetes of the young in the United Kingdom. Diabetes 1997; 46: 720-725.

4 Byrne MM, Sturis J, Menzel S et al: Altered insulin secretory responses to glucose in diabetic and non-diabetic subjects with mutations in the diabetes susceptibility gene MODY3 on Chromosome 12 . Diabetes 1996; 45: 1503-1510.

5 Lehto M, Tuomi T, Mahtani MM et al: Characterization of the MODY3 phenotype. Early-onset diabetes caused by an insulin secretion defect. J Clin Invest 1997; 99: 582-591.

6 Velho G, Vaxillaire M, Boccio V, Charpentier G, Froguel P: Diabetes complications in NIDDM kindreds linked to the MODY3 locus on chromosome 12q. Diabetes Care 1996; 19: 915-919.

7 Page RC, Hattersley AT, Levy JC et al: Clinical characteristics of subjects with a missense mutation in glucokinase. Diabetic Med 1995; 12: 209-217. 